\title{
Problematyka prawna obrotu nieruchomościami rolnymi Zasobu Własności Rolnej Skarbu Państwa w świetle nowelizacji ustawy o gospodarowaniu nieruchomościami rolnymi Skarbu Państwa z 26 kwietnia 2019 r.
}

1. Przedmiotem rozważań są zmiany w zakresie obrotu nieruchomościami rolnymi Skarbu Państwa wprowadzone ustawą z 26 kwietnia 2019 r. o zmianie ustawy o kształtowaniu ustroju rolnego oraz niektórych innych ustaw $^{1}$. Nowelizacja wpłynęła na wykonywanie przez Krajowy Ośrodek Wsparcia Rolnictwa (KOWR) uprawnień powierniczych określonych ustawą z 19 października 1991 r. o gospodarowaniu nieruchomościami rolnymi Skarbu Państwa ${ }^{2}$ w zakresie dysponowania mieniem Zasobu Własności Rolnej Skarbu Państwa. Analizowana nowela nie zmieniła jednak podstawowych regulacji obrotu gruntami skarbowymi określonych ustawą z 14 kwietnia 2016 r. o wstrzymaniu sprzedaży nieruchomości Zasobu Własności Rolnej Skarbu Państwa oraz o zmianie niektórych ustaw ${ }^{3}$. W literaturze wpływ ustawy z 2016 r. na obrót nieruchomościami rolnymi Skarbu Państwa stał się przedmiotem wielu rozważań ${ }^{4}$, natomiast zmiany w zakresie tego obrotu

${ }^{1}$ Dz. U. poz. 1080 (dalej: nowelizacja lub nowela).

2 Tekst jedn. Dz. U. 2020, poz. 396 z późn. zm. (dalej: u.g.n.r.).

3 Tekst jedn. Dz. U. 2018, poz. 869 (dalej: ustawa o wstrzymaniu sprzedaży).

${ }^{4} \mathrm{O}$ wpływie ustawy na obrót nieruchomościami Zasobu pisali m.in.: A. Suchoń, Formy zagospodarowania mienia Zasobu Własności Rolnej Skarbu Państwa po zmianie przepisów z 2016 roku, „Przegląd Prawa Rolnego” 2018, nr 2; R. Michałowski, Nowy ksztalt 
spowodowane nowelizacją z 2019 r. nie spotkały się z zainteresowaniem doktryny.

W artykule zostanie dokonana ocena skutków zmian wprowadzonych analizowaną nowelą na obrót nieruchomościami rolnymi Zasobu. Będzie ona uwzględniać zadania realizowane przez KOWR zgodnie z art. 9 ustawy z 10 lutego 2017 r. o Krajowym Ośrodku Wsparcia Rolnictwa ${ }^{5}$. Wykonywanie tych zadań, zwłaszcza w zakresie wspierania gospodarstw rodzinnych, nie jest możliwe w oderwaniu od postanowień ustawy z 11 kwietnia $2003 \mathrm{r}$. o kształtowaniu ustroju rolnego ${ }^{6}$. Dlatego analiza skutków wywołanych nowelizacją w zakresie obrotu nieruchomościami rolnymi Skarbu Państwa wymaga również uwzględnienia jej przepisów.

Za zasadnością podjęcia tego tematu przemawia znaczący wpływ nowelizacji na istotne aspekty obrotu nieruchomościami rolnymi Zasobu. Dotyczy to zwłaszcza zmian w zakresie obrotu dzierżawnego, w tym modyfikacji jego zasad wynikającej z możliwości wydzierżawiania przez KOWR ośrodków produkcji rolniczej. Równie ważne są zmiany w zakresie organizowania przez KOWR przetargów ograniczonych dla osób tworzących lub powiększających gospodarstwa rodzinne o nieruchomości rolne Zasobu.

2. Ujednolicenie zasad obrotu nieruchomościami rolnymi Zasobu z regulacjami ustawy o kształtowaniu ustroju rolnego stanowi jedną z najważniejszych zmian spowodowanych nowelizacją. W celu realizacji tego zamierzenia ustawodawca wyłączył możliwość gospodarowania przez KOWR w drodze przetargów ograniczonych nieruchomościami rolnymi Zasobu, które nie służą powiększaniu lub tworzeniu gospodarstw rodzinnych. Znowelizowany art. 24 ust. 1 pkt 1 u.g.n.r. wyklucza możliwość wydzierżawiania, a także sprzedaży przez KOWR w ramach tych przetargów nieruchomości rolnych Zasobu, których powierzchnia jest mniejsza niż 1 ha.

Wprowadzona nowelą norma powierzchniowa stanowi kryterium wyłączające możliwość rozdysponowania danej nieruchomości niezależnie od jej przeznaczenia w aktach planistycznych wymienionych w dalszej części art. 24 ust. 1 pkt 1. Obowiązywanie tej normy należy odnieść do określonej w art. 29 ust. 3 b pkt 1 u.g.n.r. konstrukcji przetargów ograniczonych, organizowanych przez KOWR dla osób zamierzających utworzyć gospodarstwo

przetargu pisemnego przy sprzedaży nieruchomości z Zasobu Własności Rolnej Skarbu Państwa, „Studia Iuridica Agraria” 2016, t. XIV; A. Perzyna, Sprzedaż państwowych gruntów rolnych - uwagi na tle nowelizacji ustawy o gospodarowaniu nieruchomościami rolnymi Skarbu Państwa (zagadnienia wybrane), „Studia Iuridica Lublinensia” 2017, t. XXVI.

5 Tekst jedn. Dz. U. 2020, poz. 481 (dalej: ustawa o KOWR).

${ }^{6}$ Tekst jedn. Dz. U. 2019, poz. 1362 (dalej: u.k.u.r.). 
rodzinne. Gospodarstwo to zgodnie z art. 5 ust. 1 u.k.u.r. stanowi kwalifikowaną postać gospodarstwa rolnego w rozumieniu Kodeksu cywilnego, z zastrzeżeniem, że powierzchnia tworzącej go nieruchomości (lub łączna powierzchnia tworzących go nieruchomości) jest nie mniejsza niż 1 ha. Analizowana zmiana jest zatem w pełni uzasadniona, gdyż dostosowuje mechanizmy wspierania gospodarstw rodzinnych przy wykorzystaniu nieruchomości rolnych Skarbu Państwa do regulacji ustawy o kształtowaniu ustroju rolnego.

O możliwości przeznaczenia nieruchomości rolnej Zasobu do rozdysponowania $\mathrm{w}$ formie przetargu ograniczonego decyduje zgodnie $\mathrm{z}$ art. 24 ust. 1 pkt 1 u.g.n.r. - oprócz kryterium powierzchniowego - jej przeznaczenie w określonych aktach planowania przestrzennego. Do przetargów tych nie mogą być na mocy tego przepisu kwalifikowane nieruchomości, które w miejscowym planie zagospodarowania przestrzennego, miejscowym planie rewitalizacji oraz miejscowym planie odbudowy zostały przeznaczone na cele inne niż rolne. W przypadku braku miejscowego planu zagospodarowania przestrzennego o możliwości rozdysponowania nieruchomości rolnej Zasobu decyduje zaś jej przeznaczenie w studium uwarunkowań i kierunków zagospodarowania przestrzennego gminy. Jeśli zgodnie z treścią tego aktu nieruchomość przeznaczona jest na cele niezwiązane z kierunkami i zasadami kształtowania rolniczej przestrzeni produkcyjnej, to nie może ona zostać wydzierżawiona ani zbyta w ramach przetargu ograniczonego.

W wyniku nowelizacji zasady kwalifikowania nieruchomości rolnych Zasobu do przetargów ograniczonych, służących wspieraniu gospodarstw rodzinnych, stały się zbieżne z regulacjami u.k.u.r. Ustawodawca powiązał bowiem możliwość rozdysponowania przez KOWR nieruchomości rolnych w tym trybie nie tylko z kryteriami funkcjonalnymi oraz faktycznymi, właściwymi kodeksowemu rozumieniu nieruchomości rolnych ${ }^{7}$, ale także z kryteriami formalnymi. Kryteria te są kluczowe dla uznania danej nieruchomości za nieruchomość rolną na potrzeby ustawy o kształtowaniu ustroju rolnego. Zgodnie z art. 2 ust. 1 tego aktu jeśli dana nieruchomość może uznana zostać za nieruchomość rolną w świetle regulacji Kodeksu cywilnego, to decydujące jest jej przeznaczenie w miejscowym planie zagospodarowania przestrzennego. W konsekwencji tego kiedy wskazany akt prawa miejscowego określa przeznaczenie nieruchomości na cele inne niż rolne, traci ona status nieruchomości rolnej w rozumieniu ustawy

${ }^{7}$ Zgodnie z art. 1 pkt 1 u.g.n.r. gospodarowanie mieniem Skarbu Państwa tworzącym Zasób obejmuje nieruchomości rolne w rozumieniu Kodeksu cywilnego, z wyłączeniem gruntów znajdujących się w zarządzie Lasów Państwowych i parków narodowych. 
o kształtowaniu ustroju rolnego i tym samym nie może wchodzić w skład gospodarstwa rodzinnego.

Należy zwrócić uwagę, że o możliwości rozdysponowania danej nieruchomości rolnej Zasobu w ramach przetargów ograniczonych decydujące są zgodnie $\mathrm{z}$ art. 24 ust. 1 pkt 1 u.g.n.r. nie tylko postanowienia miejscowego planu zagospodarowania przestrzennego, ale także studium uwarunkowań i kierunków zagospodarowania przestrzennego gminy. Postanowienia planu są natomiast jedynym wyznacznikiem o charakterze formalnym decydującym o możliwości uznania danej nieruchomości za nieruchomość rolną w świetle art. 2 pkt 1 u.k.u.r. Katalog aktów planowania przestrzennego określony w art. 24 ust. 1 u.g.n.r., pozwalający uznać nieruchomość rolną Skarbu Państwa za kwalifikującą się do rozdysponowania na potrzeby wspierania gospodarstw rodzinnych, jest więc szerszy i obejmuje nie tylko studia uwarunkowań i kierunków zagospodarowania przestrzennego gminy, ale także miejscowe plany rewitalizacji oraz miejscowe plany odbudowy.

Aby wyjaśnić tę rozbieżność, należy wskazać, że miejscowy plan rewitalizacji powinien być traktowany na równi z miejscowym planem zagospodarowania przestrzennego ${ }^{8}$. Również treść miejscowego planu odbudowy, do której odwołuje się art. 24 ust. 1 pkt 1 u.g.n.r. może przesądzać o nierolnym charakterze nieruchomości w rozumieniu ustawy o kształtowaniu ustroju rolnego.

Nowelizacja ustawy o gospodarowaniu nieruchomościami rolnymi Skarbu Państwa w analizowanym zakresie ma istotne znaczenie praktyczne. Dzięki wprowadzonej zmianie ustawodawcy udało się wyeliminować występującą uprzednio możliwość rozdysponowywania przez KOWR nieruchomości rolnych Zasobu, które w świetle przepisów ustawy o kształtowaniu ustroju rolnego nie mogły zostać uznane za wchodzące w skład gospodarstw rodzinnych. Przesądzało o tym przeznaczenie tych nieruchomości na cele inne niż rolne w miejscowych planach zagospodarowania przestrzennego. Po wprowadzonej nowelą zmianie rozdysponowanie takich nieruchomości Zasobu w trybie przetargu ograniczonego nie jest możliwe.

Ustawodawca w ramach nowelizacji dokonał również dalszych zmian w zakresie organizowania przez KOWR przetargów ograniczonych. Modyfikacji poddane zostały dotychczasowe zasady organizowania tych prze-

${ }^{8}$ Zgodnie z art. 37f ustawy z 27 marca 2003 r. o planowaniu i zagospodarowaniu przestrzennym (tekst jedn. Dz. U. 2018, poz. 1945 z późn. zm.) miejscowy plan rewitalizacji jest szczególną formą planu miejscowego. Stosownie do art. 37n ust. 2 tego aktu: „ilekroć w przepisach niniejszej ustawy albo przepisach odrębnych jest mowa o miejscowym planie zagospodarowania przestrzennego, planie miejscowym lub planach zagospodarowania przestrzennego, należy przez to rozumieć również miejscowy plan rewitalizacji”". 
targów dla osób młodych, związanych z rolnictwem, chcących rozpocząć działalność rolniczą. Taką możliwość przewiduje art. 29 ust. 3bb u.g.n.r. Zmiana dotyczy punktu 1 tego przepisu, zgodnie z którym do udziału w przetargach ograniczonych uprawnione zostały osoby, które nie ukończyły 40 lat, w przypadku gdy spełniają wymogi stawiane przez normodawcę rolnikowi indywidualnemu (poza 5-letnim okresem osobistego prowadzenia gospodarstwa rolnego).

W wyniku nowelizacji uczestnictwo w przetargu ograniczonym osób będących młodymi rolnikami skorelowane zostało z realizacją przesłanek przyznania pomocy w ramach poddziałania „Pomoc w rozpoczęciu działalności gospodarczej na rzecz młodych rolników" Programu Rozwoju Obszarów Wiejskich na lata 2014-2020 . Do przesłanek tych należy m.in. nabycie lub wejście w posiadanie gospodarstwa rolnego. Oznacza to ściślejsze powiązanie obrotu gruntami Zasobu z działaniami służącymi przyspieszeniu zmian pokoleniowych $\mathrm{w}$ rolnictwie, a więc ukierunkowanie obrotu tymi nieruchomościami do określonej grupy zawodowo-społecznej, która została wyodrębniona w ramach Wspólnej Polityki Rolnej jako kategoria prawna młodego rolnika ${ }^{10}$. W wyniku dokonanej zmiany przetargi ograniczone w większym stopniu będą służyć tworzeniu gospodarstw rodzinnych. Osoby biorące udział w tych przetargach dzięki posiadaniu wykształcenia rolniczego oraz osobistemu prowadzeniu gospodarstwa będą zaś mogły zostać rolnikami indywidualnymi ${ }^{11}$.

Kolejną zmianą w zakresie organizowania przez KOWR przetargów ograniczonych jest wyłączenie z katalogu podmiotów, które nie mogą brać udziału w tych przetargach, osób posiadających akcje lub udziały w spółkach stanowiących grupy producentów rolnych. Pierwotnie art. 29 ust. 3ba pkt 3 u.g.n.r. określał, że w przetargach ograniczonych nie mogą brać udziału osoby, które posiadają udziały lub akcje w spółkach prawa handlowego, będących właścicielami nieruchomości rolnych. Nie dotyczyło to jednak akcji dopuszczonych do obrotu na rynku giełdowym. Nowelizacja spowodowała, że wyłączenie nie dotyczy osób, które posiadają akcje i udziały w spółce będącej grupą producentów rolnych.

Zmiana ta zasługuje na aprobatę. Należy bowiem podkreślić, że reguły Wspólnej Polityki Rolnej przyznają szczególną rolę grupom producentów rolnych. Wspólne działania produkcyjne oraz organizacyjne prowadzone

9 Zob. pkt 8.2.6 Działanie „Rozwój gospodarstw i działalności gospodarczej”.

${ }_{10}$ P. Blajer, Koncepcja prawna rolnika indywidualnego $w$ prawie polskim na tle porównawczym, Kraków 2009, s. 41.

${ }^{11}$ P. Litwiniuk, Program Rozwoju Obszarów Wiejskich jako dokument programowy i źródto prawa rolnego, Warszawa 2018, s. 84. 
w ich ramach przyczyniają się do realizacji celów gospodarczych związanych z optymalizacją warunków produkcji bądź stabilizacją cen ${ }^{12}$. Ponadto tworzenie grup i organizacji producentów zostało objęte systemem wsparcia w ramach Programu Rozwoju Obszarów Wiejskich na lata 2014-202013.

Nowela wprowadziła zmiany dotyczące podmiotowych obostrzeń w zakresie organizowania przez KOWR przetargów ograniczonych, przewidzianych w art. 29 ust. 3bd u.g.n.r. Regulacja ta umożliwia KOWR zastrzeżenie, że ten sam podmiot nie może brać udziału w więcej niż jednym przetargu ograniczonym, jeżeli uprzednio został wyłoniony jako kandydat na nabywcę $\mathrm{w}$ ramach jednego $\mathrm{z}$ nich. Zastrzeżenie to może zostać dokonane przez KOWR jedynie w sytuacji, gdy poszczególne przetargi zorganizowano w celu sprzedaży wydzielonych przed przetargami części nieruchomości Zasobu lub kilku nieruchomości Zasobu znajdujących się na terenie jednego obrębu ewidencyjnego.

Pojęcie „obręb ewidencyjny” pojawiło się w treści art. 29 ust. 3bd w wyniku nowelizacji i zastąpiło pojęcie „miejscowość”. To ostatnie choć występuje w treści rozporządzenia Ministra Rozwoju Regionalnego i Budownictwa z 29 marca 2001 r. w sprawie ewidencji gruntów i budynków, nie zostało precyzyjnie dookreślone ${ }^{14}$, mimo że $\S 7$ tego aktu jednoznacznie wskazuje zakres pojęcia „obręb ewidencyjny”. Zmiana analizowanego przepisu niewątpliwie przyczyni się do skuteczniejszego zapobiegania koncentracji gruntów Zasobu w związku z uczestnictwem w przetargach ograniczonych.

3. Nowelizacja wpłynęła również na obrót dzierżawny nieruchomościami rolnymi Skarbu Państwa. Zmiany w tym zakresie mają duże znaczenie, ponieważ w związku z wejściem w życie ustawy o wstrzymaniu sprzedaży dzierżawa stała się wiodącą formą gospodarowania nieruchomościami rolnymi Zasobu. Akt ten nie zawierał jednak regulacji dotyczących tej formy obrotu, które w pełni uwzględniałaby swoistość dzierżawy gruntów państwowych. Określenie dzierżawy jako preferowanego sposobu rozdysponowania gruntów Zasobu wymagało bowiem wprowadzenia rozwiązań zapewniających trwałość stosunku prawnego dzierżawy, a także umożliwiających dzierżawcy nabycie dzierżawionych gruntów w ramach pierwszeństwa na jasnych i spójnych zasadach. Zmiany w tym zakresie wprowadzone zostały dopiero na mocy nowelizacji. W pierwszej kolejności ustawodawca złagodził skutki wyłączeń gruntów Zasobu objętych umowami dzierżawy, które są

12 B. Jeżyńska, Agroprzedsiębiorczość, w: P. Czechowski (red.), Prawo rolne, Warszawa 2019 , s. 139.

13 Zob. pkt 8.2.9 Działanie „Tworzenie grup i organizacji producentów”.

14 Tekst jedn. Dz. U. 2019, poz. 393. 
następstwem zdarzeń prawnych niezależnych od woli dzierżawcy. Nowela uprzywilejowała w dostępie do nieruchomości Zasobu dzierżawców w przypadkach, gdy wyłączenia są następstwem objęcia nieruchomości trwałym zarządem w związku z realizacją inwestycji o charakterze publicznym. Dodany do treści art. 39 ust. 2 u.g.n.r. pkt 7 przewiduje, że dzierżawcy, którzy w wyniku realizacji inwestycji utracili możliwość korzystania z dzierżawionych gruntów, zostali uprawnieni do bezprzetargowego wydzierżawienia innych nieruchomości rolnych Zasobu.

Wprowadzona zmiana ma niewątpliwie na celu zrekompensowanie dzierżawcom negatywnych następstw gospodarczych wyłączeń nieruchomości z przedmiotu dzierżawy lub w skrajnym przypadku zakończenia dotychczasowego stosunku dzierżawy. Jednak skutki przyjętego rozwiązania mogą okazać się w praktyce niekorzystne dla dzierżawców. Przyznanie możliwości bezprzetargowego wydzierżawienia nieruchomości Zasobu może bowiem zostać uznane za służące naprawieniu szkody, którą mógł ponieść dzierżawca $\mathrm{w}$ związku z dokonanymi wyłączeniami z przedmiotu dzierżawy. Skorzystanie z możliwości bezprzetargowego wydzierżawienia nieruchomości Zasobu na mocy art. 39 ust. 2 pkt 7 u.g.n.r. może więc zamykać drogę do dochodzenia przez dzierżawcę odszkodowania. Jest to tym bardziej prawdopodobne, że zgodnie z zasadą przyjętą na potrzeby tego przepisu powierzchnia wydzierżawianej bezprzetargowo nieruchomości, wyrażona w hektarach przeliczeniowych, nie powinna być większa od wyłączonej z umowy dzierżawy. Ustawodawca dąży tym samym do zagwarantowania ekwiwalentności w zakresie przydatności produkcyjnej gruntów, które wydzierżawiane są w związku z wyłączeniami. Hektar przeliczeniowy jest uznawany bowiem za konstrukcję służącą badaniu miary dochodowości gruntów rolnych ${ }^{15}$. Rozwiązanie to nie gwarantuje jednak, że objęte przez dzierżawcę na mocy art. 39 ust. 2 pkt 7 u.g.n.r. grunty Zasobu pod względem gospodarczym będą równoważne gruntom wyłączonym z umowy dzierżawy. Ustawodawca nie uwzględnia bowiem w tym zakresie kwestii wpływu dokonanych wyłączeń z umowy dzierżawy na rozłóg gruntów tworzących gospodarstwo dzierżawcy.

Wzmocnieniu pozycji dzierżawcy jako słabszej strony stosunku prawnego łączącego go z państwową osobą prawną, którą jest KOWR, służy niewątpliwie wprowadzony do treści art. 29 u.g.n.r. ust. 1aa. Uzasadnieniem działań ustawodawcy w tym zakresie jest sytuacja prawna dzierżawcy nieruchomości rolnych Skarbu Państwa, która różni się od sytuacji prawnej dzierżawcy gruntów prywatnych. Najdobitniej wyraża to brak możliwości

${ }^{15}$ L. Etel, Podatek rolny i leśny, Warszawa 2012, s. 114. 
nabycia dzierżawionych gruntów Zasobu w ramach prawa pierwokupu, które przysługuje dzierżawcy na mocy art. 3 ust. 1 u.k.u.r. Zgodnie z art. 29 ust. 1 pkt 3 u.g.n.r. dzierżawcy gruntów Skarbu Państwa przyznana została bowiem możliwość nabycia dzierżawionych nieruchomości w ramach pierwszeństwa w nabyciu. Co do zasady pierwszeństwo w nabyciu w znacznie mniejszym stopniu zabezpiecza interesy dzierżawcy aniżeli osoby uprawnionej z tytułu ustawowego prawa pierwokupu ${ }^{16}$. Konstrukcja pierwszeństwa, określona art. 29 ust. 1 pkt 3 u.g.n.r., osłabia pozycję osoby gospodarującej na gruntach Skarbu Państwa poprzez powiązanie legitymacji w zakresie ich nabycia z wymogiem, aby umowa dzierżawy trwała faktycznie przez okres 3 lat. Faktyczne trwanie dzierżawy, o którym mowa w tym przepisie, jest rozumiane przy tym jako nieprzerwany bieg tego stosunku przy zachowaniu tożsamości jego stron. Ma to znaczenie dla stosowania art. 39c u.g.n.r., który został wprowadzony przez ustawę o wstrzymaniu sprzedaży. Regulacja ta dopuszcza $\mathrm{w}$ określonych przypadkach przeniesienie praw i obowiązków wynikających z umowy dzierżawy nieruchomości Zasobu na osoby bliskie dzierżawcy. Dopuszczenie przez ustawodawcę zmian podmiotowych w umowach dzierżawy nie korespondowało jednak z określonym w art. 29 ust. 1 pkt 3 u.g.n.r. wymogiem faktycznego trwania stosunku dzierżawy, jako przesłanki umożliwiającej skorzystanie z pierwszeństwa w nabyciu. W celu usunięcia niespójności przepisów w tym zakresie na mocy nowelizacji do okresu faktycznego trwania umowy dzierżawy zalicza się nie tylko okres dzierżawy dotychczasowego dzierżawcy, ale także podmiotów, które wstąpiły w stosunek dzierżawy na podstawie art. 39c. Ponadto ustawodawca rozciągnął możliwość zaliczenia do okresu niezbędnego do skorzystania z pierwszeństwa w nabyciu nieruchomości, które zostały wydzierżawione bezprzetargowo, okresu umowy dzierżawy nieruchomości wyłączonych z umowy dzierżawy.

Duże znaczenie dla wzmocnienia pozycji dzierżawcy gruntów rolnych Zasobu ma również zmiana wprowadzona nowelą do treści art. 38 u.g.n.r. ${ }^{17}$ Na mocy dodanego ust. $1 \mathrm{~b}$ pkt 1 ustawodawca w sposób jednoznaczny przesądził, że do umów dzierżawy nieruchomości Zasobu nie stosuje się art. 695 k.c. Powyższe unormowanie ma na celu rozstrzygnięcie kwestii możliwości przekształcenia co do zasady terminowej umowy dzierżawy nieruchomości Zasobu w umowę zawartą na czas nieokreślony.

Przepisy u.g.n.r. z jednej strony wskazują bowiem, że umowy dzierżawy nieruchomości Zasobu zawierane są na czas oznaczony (art. 24 ust. 2),

${ }^{16}$ K. Świderski, Charakter prawny pierwszeństwa w nabyciu nieruchomości, „Rejent” 2000, nr 11, s. 84; B. Burian, Pierwszeństwo nabycia nieruchomości, Kraków 2004, s. 199.

17 Art. 3 pkt 12 lit a nowelizacji. 
z drugiej - nie wykluczają możliwości zawierania takich umów na czas nieoznaczony (art. 38 ust. 1a oraz art. 39 ust. 5). Niemniej zgodnie z dyspozycją art. 24 ust. 2 KOWR zawiera umowy dzierżawy jedynie na czas określony. Nie oznacza to jednak, że umowy dzierżawy gruntów Zasobu nie mogły, wskutek faktycznego okresu ich trwania przekraczającego 30 lat, przekształcić się na mocy art. 695 k.c. w umowy zawarte na czas nieokreślony. Wyłączenie przez nowelę możliwości stosowania tego przepisu na potrzeby ustawy o gospodarowaniu nieruchomościami rolnymi oznacza, że w praktyce umowy dzierżawy nieruchomości Zasobu będą miały charakter umów terminowych. Zmianę w tym zakresie należy uznać za służącą zwiększeniu trwałości stosunku dzierżawy. Pozwoli to na uniknięcie niekorzystnych dla dzierżawców skutków prawnych, które rodzi przekształcenie umowy dzierżawy zawartej na czas określony w umowę bezterminową, w zakresie możliwości jej rozwiązania z zachowaniem krótszego okresu wypowiedzenia.

4. Szczególnie ważny w kontekście zmian regulacji normujących obrót nieruchomościami rolnymi Zasobu jest wprowadzony przez nowelizację do u.g.n.r. art. $24 b^{18}$. Przepis ten przewiduje możliwość wydzierżawiania przez KOWR ośrodków produkcji rolniczej. Zgodnie z jego treścią ośrodki te tworzą wyodrębnione z Zasobu nieruchomości oraz inne składniki mienia, stanowiące nierozerwalną, zorganizowaną całość gospodarczą, o powierzchni przekraczającej 50 ha, której podział byłby nieuzasadniony ekonomicznie.

Wyodrębnienia mienia tworzącego ośrodek dokonuje dyrektor generalny KOWR po uzyskaniu zgody ministra właściwego do spraw rozwoju wsi. W tym zakresie rodzi się pytanie o naturę prawną tych czynności. Literalne brzmienie przepisu art. 24b wskazuje, że na skutek działań dyrektora generalnego KOWR dochodzi do wyodrębnienia nieruchomości oraz mienia z Zasobu, a więc de facto wyłączenia go z Zasobu. Przyjęcie powyższej literalnej wykładni oznaczałoby jednak, że mienie to przestaje być przedmiotem stosunku powiernictwa. Zgodnie bowiem z art. 5 ust. 1 u.g.n.r. Skarb Państwa powierza KOWR wykonywanie prawa własności i innych praw rzeczowych na jego rzecz w stosunku do mienia tworzącego Zasób, przy czym wykonywanie tych praw następuje z momentem przekazania mienia do Zasobu $\mathrm{w}$ trybie wskazanym $\mathrm{w}$ tym akcie ${ }^{19}$. Tym samym literalnie rozumiane czynności wyodrębnienia ośrodka z Zasobu

\footnotetext{
${ }^{18}$ Art. 3 pkt 6 nowelizacji.

19 R. Pessel, Nieruchomości Skarbu Państwa, Warszawa 2008, s. 111.
} 
oznaczałyby, że tworzące go mienie przestałoby być przedmiotem stosunku powiernictwa. Można wówczas założyć, że mienie to po wyłączeniu z Zasobu stałoby się mieniem KOWR, a więc odrębnym od Zasobu substratem majątkowym będącym własnością tego podmiotu (nie zaś Skarbu Państwa). Przedstawiona wykładnia jest jednak nie do zaakceptowania z uwagi na regulacje ustawy o gospodarowaniu nieruchomościami rolnymi oraz ustawy o KOWR. Ustawodawca powinien więc wskazać, że dyrektor generalny KOWR dokonuje wyodrębnienia nieruchomości i innego mienia tworzącego ośrodek w ramach Zasobu. Bez wątpienia bowiem mienie tworzące ośrodek pozostanie w Zasobie, samo zaś wyodrębnienie będzie miało charakter organizacyjny, a nie prawny.

Definicja legalna ośrodka zawarta w art. 24b ust. 1 u.g.n.r., wyrażająca sposób rozumienia tego pojęcia przez prawodawcę, wskazuje jednocześnie kryteria pozwalające na wyodrębnienie tych jednostek z pozostałego mienia Zasobu. Przepis ten odnosi się do czynników materialnych (nieruchomości) oraz mienia innego niż nieruchomości, a więc również czynników niematerialnych - praw majątkowych. Składniki te ustawodawca łączy za pomocą więzi organizacyjno-funkcjonalnej, za którą należy uznać wymóg, aby tworzyły one „nierozerwalną, zorganizowaną całość gospodarczą”. Tym samym na gruncie prawa cywilnego ośrodki można uznać za rodzaj zorganizowanych mas majątkowych. Wobec tego zasadne jest rozpatrywanie ich statusu prawnego jako gospodarstw rolnych (art. $55^{3}$ k.c.) bądź przedsiębiorstw rolnych (w rozumieniu art. $55^{1}$ k.c.).

Zgodnie $\mathrm{z}$ art. $55^{3}$ k.c. gospodarstwo rolne stanowi masę majątkową, w skład której wchodzą składniki stanowiące zorganizowany, spójny system gospodarczy zdolny do osiągania założonych celów, tj. prowadzenia działalności produkcyjnej w rolnictwie ${ }^{20}$. Podstawę gospodarstwa rolnego zgodnie $\mathrm{z}$ art. $55^{3}$ k.c. stanowi mienie rozumiane jako składniki materialne oraz składniki niematerialne, które tworzą związek organizacyjno-funkcjonalny zapewniający gospodarstwu jedność techniczno-ekonomiczną ${ }^{21}$. Organizacja masy majątkowej, którą stanowi gospodarstwo rolne, jest jednak zawsze podporządkowana realizacji przyjętego celu ekonomicznego. W takim ujęciu ośrodki określone jako nierozerwalna, zorganizowana całość gospodarcza, służąca prowadzeniu produkcji rolniczej, są niewątpliwie gospodarstwami

${ }^{20}$ P. Czechowski, A. Niewiadomski, Gospodarstwo rolne jako masa majątkowa, „Studia Iuridica Agraria” 2009, t. 8, s. 48. Traktowanie gospodarstwa rolnego jako zorganizowanej masy majątkowej zostało zaaprobowane przez judykaturę, czego przejawem jest m.in. wyrok Sądu Najwyższego z 10 lutego 2004 r. (sygn. IV CK 12/03).

${ }^{21}$ R. Budzinowski, Gospodarstwo rolne a przedsiębiorstwo rolne, w: A. Stelmachowski (red.), Prawo rolne, Warszawa 2008, s. 59. 
rolnymi. Tym niemniej przyjęcie tego założenia wymaga odniesienia się do strony przedmiotowej tych jednostek, która to strona jest istotnym elementem definicji określonej art. $55^{3}$ k.c. Według art. $24 \mathrm{~b}$ u.g.n.r. ośrodki stanowią wyodrębnioną masę majątkową, na którą w pierwszej kolejności składają się nieruchomości Zasobu. Co znamienne, ustawodawca nie wskazał, że ośrodek tworzą nieruchomości rolne Zasobu. Skoro jednak posługuje się on pojęciem ośrodków produkcji rolniczej, należy założyć, że będą one wyodrębniane przede wszystkim z nieruchomości rolnych Zasobu. Dlatego wskazane byłoby, aby ustawodawca oparł definicję ośrodków na pojęciu nieruchomości rolnej, wskazując jednocześnie, że w ich skład mogą wchodzić również nieruchomości inne niż rolne, jeżeli stanowią wraz z mieniem rolnym nierozerwalną, zorganizowaną całość gospodarczą.

Założenie, że konstrukcja normatywna ośrodków uprawnia do uznania ich za szczególny rodzaj gospodarstwa rolnego, uprawdopodabnia także identyfikowanie ich jako przedsiębiorstw rolnych. Nie ulega bowiem wątpliwości, że pojęcia gospodarstwa rolnego oraz przedsiębiorstwa rolnego można uznać za zbliżone ${ }^{22}$.

Na gruncie art. $55^{1}$ k.c. przedsiębiorstwo należy traktować jako zorganizowany zespół składników materialnych i niematerialnych przeznaczonych do prowadzenia działalności gospodarczej ${ }^{23}$. W tym względzie należy zwrócić uwagę, że pomimo wyraźnego wyłączenia działalności rolniczej z regulacji ustawy z 6 marca 2018 r. Prawo przedsiębiorców ${ }^{24}$ nie można założyć, że działalność wytwórcza w rolnictwie nie jest działalnością gospodarczą $\mathrm{w}$ rozumieniu tej ustawy ${ }^{25}$. Wniosek ten ma znaczenie w zakresie regulacji art. $24 \mathrm{~b}$ ust. 1 u.g.n.r. jako przepisu określającego tworzenie jednostek służących prowadzeniu działalności produkcyjnej w rolnictwie. Zaakcentowanie w treści art. 24b ust. 1 u.g.n.r. kwestii doboru mienia tworzącego ośrodek przy wyraźnym zastosowaniu kryterium ekonomicznego znajduje potwierdzenie w przyjętych przez KOWR procedurach, które wskazują, że wyodrębnienie

${ }^{22}$ R. Budzinowski, Gospodarstwo rolne a przedsiębiorstwo rolne, w: P. Czechowski (red.), Prawo rolne, Warszawa 2017, s. 118. Należy zaznaczyć, że Trybunał Konstytucyjny przyjął, iż wobec uznania działalności rolniczej za działalność gospodarczą uprawnione jest przyjęcie, że gospodarstwo rolne stanowi de facto rodzaj przedsiębiorstwa (wyrok TK z 31 stycznia 2001 r., sygn. P 4/99; por. K. Czerwińska-Koral, Pojęcie gospodarstwa rolnego w Kodeksie cywilnym - zagadnienia wybrane, „Roczniki Administracji i Prawa” 2013, t. 1, s. 393).

23 A. Kidyba, Prawo handlowe, Warszawa 2006, s. 32.

${ }^{24}$ Tekst jedn. Dz. U. 2019, poz. 1292 z późn. zm.

${ }^{25}$ Zgodnie z uchwałą Naczelnego Sądu Administracyjnego z 2 kwietnia 2007 r. (sygn. II OPS 1/07) należy przyjąć, że działalność rolnicza nie podlega jedynie reżimowi tej ustawy. 
z Zasobu mienia tworzącego ośrodek będzie odbywać się z uwzględnieniem działu produkcji rolniczej, która będzie w nim prowadzona, tak aby mienie to zostało skonfigurowane w sposób maksymalizujący prowadzoną w nim produkcję towarową ${ }^{26}$.

Wyodrębnienie mienia Zasobu tworzącego ośrodek będzie prowadzić w sensie faktycznym do utworzenia gospodarstwa rolnego. Przyjęta przez KOWR praktyka wykonywania art. $24 \mathrm{~b}$ ust. 1 u.g.n.r., wyrażona w treści powoływanego zarządzenia, wskazuje, że w praktyce wyodrębnienie mienia z Zasobu na podstawie tego przepisu będzie służyć powstawaniu przedsiębiorstw rolnych, tj. jednostek, w których będzie prowadzona produkcja towarowa. W konsekwencji ośrodki te powinny być traktowane jako przedsiębiorstwa rolne, służące prowadzeniu na mieniu Zasobu działalności rolniczej ukierunkowanej na wprowadzanie wytworzonych produktów na rynek w celu osiągnięcia zysku ${ }^{27}$.

Zgodnie z treścią art. $24 \mathrm{~b}$ ust. 2 u.g.n.r. KOWR gospodaruje ośrodkami poprzez oddanie ich na czas oznaczony do odpłatnego korzystania na zasadach określonych w rozdziale 8 u.g.n.r. Zgodnie $\mathrm{z}$ art. 38 ust. 1 u.g.n.r., otwierającym ten rozdział, ośrodek może być przedmiotem dzierżawy, najmu lub tzw. leasingu rolniczego ${ }^{28}$. Wątpliwości w zakresie formy rozdysponowania ośrodka rozwiewa jednak treść ust. 3 art. 24b, zgodnie z którą KOWR zawiera umowę dzierżawy ośrodka po przeprowadzeniu przetargu. Dodatkowo w ust. 5 tego przepisu ustawodawca wskazał, że umowa dzierżawy ośrodka zawierana jest $\mathrm{w}$ formie pisemnej pod rygorem nieważności. Bez wątpienia więc korzystanie z mienia Zasobu tworzącego ośrodki może następować tylko i wyłącznie w drodze dzierżawy. Przy okazji należy zwrócić uwagę na znaczącą modyfikację w zakresie wydzierżawiania ośrodków, wywołaną art. $24 \mathrm{~b}$ u.g.n.r., względem generalnych zasad wydzierżawienia nieruchomości rolnych Zasobu. Zgodnie z treścią art. 24 ust. 1 u.g.n.r. formą domyślną wyłaniania dzierżawców nieruchomości rolnych Zasobu jest przetarg ograniczony. Tymczasem zgodnie $\mathrm{z}$ art. 24b ust. 3 zawarcie umowy dzierżawy ośrodka następuje po przeprowadzeniu przetargu, w którym mogą brać udział osoby fizyczne lub prawne. W przypadku gdy ośrodek będą tworzyć

26 Zarządzenie Dyrektora Generalnego KOWR nr 47/2019 z 4 lipca 2019 r. w sprawie wydzierżawiania nieruchomości Zasobu Własności Rolnej Skarbu Państwa.

${ }^{27}$ R. Budzinowski, A. Suchoń, Relacja gospodarstwa rolnego i przedsiębiorstwa rolnego $w$ świetle publicznych mechanizmów ich wspierania, w: P. Litwiniuk (red.), Prawne mechanizmy wspierania i ochrony rolnictwa rodzinnego $w$ Polsce i innych państwach Unii Europejskiej, Warszawa 2015, s. 325.

${ }_{28}$ K. Marciniuk, w: P. Czechowski (red.), Ustawa o gospodarowaniu nieruchomościami rolnymi Skarbu Państwa. Komentarz, Warszawa 2018, s. 278. 
nieruchomości rolne Zasobu w rozumieniu art. 24 ust. 1 u.g.n.r., pojawia się wątpliwość, czy KOWR będzie uprawniony do ogłoszenia przetargu ograniczonego, tj. organizowanego jedynie dla osób fizycznych. Wydaje się, że przyjęcie zawężającej wykładni, dopuszczającej udział w przetargu tylko tej grupy podmiotów, może stanowić nieuprawnione zawężenie dostępu do mienia publicznego. Ustawodawca wskazał bowiem w treści art. 24b, że w przetargu na dzierżawę może uczestniczyć osoba fizyczna lub prawna. Oznacza to, że obie grupy podmiotów uprawnione są do ubiegania się o udział w przetargu na dzierżawę ośrodka, a art. 24b stanowi przepis szczególny względem art. 24 ust. 1 u.g.n.r.

Odmiennie od regulacji normujących wydzierżawianie mienia Zasobu, w art. 24 b ust. 5 zawarty został katalog obligatoryjnych postanowień umowy dzierżawy, której przedmiotem jest ośrodek. W umowie dzierżawy ośrodka określa się: warunki prowadzenia działalności rolniczej na przedmiocie dzierżawy, przypadki powodujące możliwość wypowiedzenia umowy przed upływem okresu, na jaki została zawarta, przypadki powodujące zmianę wysokości czynszu oraz minimalną liczbę pracowników, jaką zobowiązany będzie zatrudniać dzierżawca. Powstaje jednak wątpliwość co do sposobu ustalania treści powyższych postanowień umowy. Ze względu na licytacyjny tryb przetargu na dzierżawę ośrodka należy przyjąć, że nie będą one częścią oferty i jako takie nie będą podlegać ocenie. Przepis art. 24b nie wskazuje bowiem na możliwość wydzierżawienia ośrodka w trybie ofertowym. Należy więc założyć, że warunki umów dzierżawy ośrodków będą określane w sposób jednostronny przez KOWR i jako takie nie będą podlegały uzgodnieniu z dzierżawcą.

5. Pomimo obowiązywania ustawowego ograniczenia sprzedaży gruntów rolnych Zasobu nowelą dokonano również modyfikacji w zakresie własnościowego obrotu nieruchomościami rolnymi Zasobu. Zgodnie $\mathrm{z}$ art. 3 pkt 8 tego aktu ustawodawca wprowadził wyjątek w bezwzględnie obowiązującej normie obszarowej określonej w art. 28a ust. 1 u.g.n.r. Przepis ten uniemożliwia KOWR sprzedaż nieruchomości rolnej Zasobu, jeżeli w jej wyniku łączna powierzchnia użytków rolnych będących własnością nabywcy przekroczy 300 ha, przy czym do powierzchni tej ustawodawca nakazał wliczać powierzchnię nieruchomości nabytych kiedykolwiek z Zasobu. Zgodnie z przywołanym przepisem noweli powyższego limitu powierzchniowego nie stosuje się natomiast do nabywanych nieruchomości, w których grunty oznaczone w ewidencji gruntów i budynków jako grunty pod stawami stanowią co najmniej $70 \%$ powierzchni.

Wobec ustawowego ograniczenia sprzedaży nieruchomości rolnych Zasobu znaczenie tego przepisu należy rozpatrywać w aspekcie nabywania 
tych nieruchomości przez dzierżawców w ramach pierwszeństwa w nabyciu. Wprowadzenie odstępstwa od reguły określonej w art. 28a ust. 1 u.g.n.r. wydaje się w pełni zasadne, gdyż umożliwia dzierżawcy nabycie w drodze pierwszeństwa przedmiotu dzierżawy, który obejmuje obiekty stawowe, mające zazwyczaj charakter wielkopowierzchniowy.

6. Powyższe rozważania, odnoszące się do najważniejszych zmian w zakresie obrotu nieruchomościami rolnymi Zasobu, spowodowanych ustawą nowelizującą z 26 kwietnia 2019 r., pozwalają rozpatrywać regulacje tego aktu jako statuującego zmiany o charakterze systemowym. Ustawodawca, zapewniając zbieżność pojęcia nieruchomości rolnej na potrzeby obrotu nieruchomościami Zasobu z pojęciem nieruchomości rolnej występującym w ustawie o kształtowaniu ustroju rolnego, spowodował, że obrót nieruchomościami skarbowymi służy (podobnie jak obrót rynkowy) wspieraniu gospodarstw rodzinnych. Ma to szczególne znaczenie z uwagi na prymat przetargów ograniczonych jako podstawowej formy rozdysponowania nieruchomości rolnych Skarbu Państwa, służącej w założeniu tworzeniu i powiększaniu tego typu gospodarstw. Jednak dla zachowania spójności regulacji obu aktów istotne jest też stosowanie jednakowej wykładni pojęcia nieruchomości rolnej. W tym celu należy przyjąć, że interpretacja przepisów ustawy o kształtowaniu ustroju rolnego, która została wypracowana w ramach porozumienia między Ministerstwem Rolnictwa i Rozwoju Wsi, Krajowym Ośrodkiem Wsparcia Rolnictwa oraz Krajową Radą Notarialną, znajdzie odpowiednie zastosowanie do obrotu nieruchomościami rolnymi Zasobu Własności Rolnej Skarbu Państwa ${ }^{29}$. Jest to niezbędne w odniesieniu do nieruchomości, które rozdysponowywane będą $\mathrm{w}$ wyniku przetargów ograniczonych, a których przeznaczenie w miejscowych planach zagospodarowania przestrzennego ma charakter mieszany (nieruchomość objęta jest zapisami, które określają jej przeznaczenie jednocześnie na cele rolne oraz cele inne niż rolne).

Niezależnie od tego zgodnie ze znowelizowanym brzmieniem art. 24 ust. 1 u.g.n.r. status danej nieruchomości Zasobu jako nieruchomości rolnej określany jest m.in. na podstawie studium uwarunkowań i kierunków zagospodarowania przestrzennego gminy. Do dokumentu tego nie odwołuje się natomiast art. 2 pkt 1 u.k.u.r. W tym zakresie należy więc postulować

${ }^{29}$ Wspólne stanowisko Ministerstwa Rolnictwa i Rozwoju Wsi, Krajowego Ośrodka Wsparcia Rolnictwa oraz Krajowej Rady Notarialnej z 27 lutego 2020 r. w sprawie stosowania w praktyce przepisów ustawy z 11 kwietnia 2003 r. o kształtowaniu ustroju rolnego, https://www.kowr.gov.pl/pobierz-plik/388633 [dostęp: 28.02.2020]. 
o dokonanie zmian regulacji tego ostatniego aktu ${ }^{30}$. Jest to uzasadnione tym, że plany zagospodarowania przestrzennego, będące jedynym aktem planowania przestrzennego, do którego odwołują się regulacje ustawy o kształtowaniu ustroju rolnego, obejmują zaledwie $30 \% \mathrm{kraju}^{31}$, podczas gdy studium uwarunkowań i kierunków zagospodarowania przestrzennego, którego sporządzenie przez radę gminy jest obowiązkowe, ma charakter powszechny. Realizacja tego postulatu usprawniłaby identyfikację rolnego charakteru nieruchomości na obszarach, na których nie obowiązują plany zagospodarowania przestrzennego.

Nowelizacja przyczyniła się również do wzmocnienia trwałości stosunku dzierżawy, co należy ocenić pozytywnie. W tym zakresie doszło do zwiększenia ochrony dzierżawcy poprzez uniemożliwienie wypowiedzenia umowy dzierżawy z zachowaniem skróconego terminu jako umowy bezterminowej. Jednocześnie nowela zracjonalizowała przesłanki korzystania z pierwszeństwa w nabyciu, wskutek czego nabycie nieruchomości Zasobu $\mathrm{w}$ tym trybie będzie mogło następować z uwzględnieniem możliwości dokonywania zmian podmiotowych po stronie dzierżawcy, a więc mechanizmu, który wcześniej został dopuszczony przez ustawodawcę. Służyć to będzie wzmocnieniu pozycji dzierżawcy jako samodzielnego producenta rolnego i zachęcać do prowadzenia racjonalnej gospodarki na dzierżawionych gruntach Skarbu Państwa, opartej na wieloletnim planowaniu inwestycyjno-produkcyjnym ${ }^{32}$.

Pomimo dokonanych zmian pozycja dzierżawcy gruntów rolnych Zasobu Własności Rolnej Skarbu Państwa jest inna niż dzierżawcy gruntów prywatnych. Pierwszeństwo w nabyciu stanowi konstrukcję prawną, która znacznie słabiej chroni interesy dzierżawcy nieruchomości rolnych Skarbu Państwa niż prawo pierwokupu przysługujące dzierżawcom na podstawie ustawy o kształtowaniu ustroju rolnego. Należy więc rozważyć możliwość zastąpienia instytucji pierwszeństwa w nabyciu określonej w art. 29 ust. 1 pkt 3 u.g.n.r. instytucją pierwokupu ${ }^{33}$. W obecnym stanie prawnym nie ma

${ }^{30}$ Podobnie K. Marciniuk, Pojęcie nieruchomości rolnej jako przedmiotu reglamentacji obrotu własnościowego, „Studia Iuridica Lublinensia” 2017, nr 26, s. 111.

${ }^{31}$ OECD Przeglądy Polityk Rozwoju Obszarów Wiejskich: Polska 2018, https://www. oecd.org/cfe/oecd-przeglady-polityk -rozwoju-obszarow- wiejskich-polska-2018-97883761 06625-pl.htm, s. 211 [dostęp: 28.02.2020].

32 A. Suchoń, Z prawnej problematyki gospodarowania na dzierżawionych gruntach rolnych, „Studia Iuridica Agraria” 2011, t. IX, s. 72.

33 Do 26 września 1994 r., tj. wejścia w życie ustawy z 7 lipca 1994 r. o zmianie ustawy - Prawo spółdzielcze oraz o zmianie niektórych innych ustaw (Dz. U. Nr 90, poz. 419), zgodnie z art. 29 ust. 1 u.g.n.r. dzierżawcy nieruchomości Zasobu mogli nabywać przedmiot dzierżawy na podstawie prawa pierwokupu. 
bowiem uzasadnienia różnicowania przez ustawodawcę sytuacji prawnej dzierżawców nieruchomości Zasobu oraz nieruchomości prywatnych.

Wprowadzona nowelą konstrukcja ośrodków produkcji rolniczej stanowi atrakcyjną formę obrotu nieruchomościami rolnymi Zasobu Własności Rolnej Skarbu Państwa, która stwarza możliwość wydzierżawiania zorganizowanych pod względem funkcjonalnym jednostek produkcyjnych, w których prowadzona będzie produkcja o charakterze towarowym. Będzie to sprzyjać powstawaniu przedsiębiorstw rolnych i umożliwi Krajowemu Ośrodkowi Wsparcia Rolnictwa gospodarowanie powierzonym mu mieniem w warunkach jego racjonalnego zagospodarowania. Jednakże wyłączanie znacznych areałów gruntów Skarbu Państwa, które będą wchodzić w skład ośrodków produkcji rolniczej, może stać się zarzewiem konfliktów między większymi producentami rolnymi a rolnikami indywidualnymi. Ci ostatni mogą postrzegać organizowanie przez KOWR jednostek obejmujących ponad 50 ha gruntów Zasobu Własności Rolnej Skarbu Państwa jako tworzenie warunków sprzyjających nadmiernej ich koncentracji kosztem gospodarstw rodzinnych. Możliwość oceny wpływu art. 24b na proces gospodarowania nieruchomościami rolnymi Zasobu będzie jednak wymagać poznania problemów, które ujawnią się w praktyce stosowania tej regulacji.

\title{
LEGAL ISSUES RELATED TO THE TRADING IN AGRICULTURAL REAL ESTATE OF THE TREASURY AGRICULTURAL PROPERTY STOCK IN THE LIGHT OF THE AMENDMENT TO THE ACT ON MANAGEMENT OF AGRICULTURAL PROPERTY OF THE TREASURY OF 26 APRIL 2019
}

\author{
Summary
}

The article assesses the impact of the Act of 26 April 2019 amending the Act on shaping the agricultural system and certain other acts on trading in agricultural property of the Treasury Agricultural Property Stock. The amendment significantly changed the rules of managing agricultural property of the State Treasury carried out by the National Agricultural Support Centre. In particular, the changes concerned the organisation of restricted tenders aimed at supporting family agricultural holdings, strengthening the position of the tenant of the State Treasury agricultural land as well as the creation of agricultural production centers by the National Agricultural Support Centre. The author points out the practical consequences of the changes and formulates de lege ferenda conclusions. 


\title{
QUESTIONI GIURIDICHE RELATIVE ALLA COMPRAVENDITA DI IMMOBILI AGRICOLI DEL PATRIMONIO DELL'AGENZIA FONDIARIA AGRICOLA TESORO DI STATO ALLA LUCE DELLA MODIFICA LEGISLATIVA APPORTATA ALLA LEGGE SULLA GESTIONE DEGLI IMMOBILI AGRICOLI TESORO DI STATO DEL 26 APRILE 2019
}

\begin{abstract}
Riassunto
L'articolo si propone di valutare l'influenza della legge del 26 aprile 2019, che modifica la legge sul regime agricolo, e di alcune altre leggi esercitata nell'ambito della compravendita di immobili del patrimonio dell'Agenzia fondiaria agricola Tesoro di Stato. La modifica legislativa apportata ha cambiato in modo significativo le regole di gestione degli immobili agricoli Tesoro di Stato da parte del Centro nazionale per il sostegno all'agricoltura. Nello specifico, le modifiche hanno riguardato l'organizzazione di gare d'appalto ristrette, a sostegno delle aziende agricole a conduzione familiare, il rafforzamento della posizione del locatario dei terreni Tesoro di Stato, nonché la creazione di centri di produzione agricola da parte del Centro nazionale di sostegno all'agricoltura. L'autore mette in rilievo le conseguenze pratiche delle modifiche evocate e formula conclusioni de lege ferenda.
\end{abstract}

